\title{
The Genetics of Anthocyanin Pigmentation (of Colour) and Chlorophylls Content of $G$. hirsutum L. Cotton Plant
}

\author{
Ya. B. Tursunov ${ }^{1}$, M. F. Abzalov ${ }^{2}$ \\ ${ }^{1}$ Laboratory of Experimental Biology and Ecology, Andizhan State University, Andizhan, Uzbekistan \\ ${ }^{2}$ Institute of Genetics and Plant Experimental Biology, Academy of Sciences of the Republic of Uzbekistan, Tashkent, Uzbekistan \\ Email: agsu_info@edu.uz,igebr_anruz@mail.ru
}

How to cite this paper: Tursunov, Y.B. and Abzalov, M.F. (2020) The Genetics of Anthocyanin Pigmentation (of Colour) and Chlorophylls Content of G. hirsutum L. Cotton Plant. American Journal of Plant Sciences, 11, 1405-1413.

https://doi.org/10.4236/ajps.2020.119101

Received: August 4, 2020

Accepted: September 15, 2020

Published: September 18, 2020

Copyright $\odot 2020$ by author(s) and Scientific Research Publishing Inc. This work is licensed under the Creative Commons Attribution International License (CC BY 4.0).

http://creativecommons.org/licenses/by/4.0/

\begin{abstract}
In the article, the first time genes of anthocyanin pigmentation $R_{p}$ and $R_{s t}{ }^{v}$ appeared in cotton plant interacting complementarily. Recessive homozygosis $r_{p} r_{p} r_{s t}{ }^{v} r_{s t}{ }^{v}$ conditions the development of green colour. The gen $R_{p}$ conditions the development of anthocyanin in all organs of plants, $R_{s t}{ }^{v}$ only exists on the stalk and in the nerves of leaves, the flower is uncolored, the boll is green. The plants' existence in genotype of both dominant equilocal genes $\left(R_{p}, R_{s t}\right)$ provides a high rate of biosynthesis of anthocyanin-dark red. Inheritance of the chlorophylls "a" + "b" and "a" and "b" quantity in anthocyanin coloured L-2 and L-3 lines of $F_{1}$ and $F_{2}$ generations. The quantity of chlorophylls in anthocyanin coloured L-3 line was defined 1.0 - 1.5 times higher and participation of the gen $\mathrm{R}_{\mathrm{st}} \mathrm{v}$ responsible for anthocyanin colour in chlorophylls biosynthesis was also defined. Apparently, in the line L-3 in $\mathrm{R}_{\mathrm{st}}{ }^{\mathrm{v}}$ is localized, there are gens which are responsible for the quantity of chlorophyll or $\mathrm{R}_{\mathrm{st}}{ }^{\mathrm{v}}$ has pleiotropic effects on the quantity of chlorophyll. It is proved with low quantity of chlorophyll in green coloured plants by recessive homozygote condition $r_{p} r_{p} r_{s t}{ }_{s t} r_{s t}{ }^{v}$ green colour.
\end{abstract}

\section{Keywords}

Gen, Genotype, Complementary, Anthocyanins, Chlorophyll, Dominance

\section{Introduction}

Research of the anthocyanin pigmentation genetics is of great interest for explanation of the stages of realization of genetic information in ontogenesis. It was revealed that its huge variety, and mutation on this basis do not significantly af- 
fect the viability of the organism

In plants of Gossypium L. genus, anthocyanin color is distributed evenly and unevenly along the vegetative and generative parts.

According to existing literature data [1], in old-world types of cotton, six series $\left(R, R^{1} R^{c}, R s, r^{0}\right.$ and $\left.r^{g}\right)$ of anthocyanin allelomorphs were identified, capturing different plant organs and appearing as a result of the interaction of a series of multiple allelomorphs. Harland [2] proposed symbolism of anthocyanin pigmentation genes and classified their phenotypic manifestation according to organs. Considering from the point of view of evolution, anthocyanin pigmentation in the new-born species of cotton, Stephens [3] proposed gene loci, as well as their phenotypic effect. Kohel [4] assigned the gene responsible for the anthocyanin coloration of the plant $R_{1}$ to the III linkage group, and the $R_{2}$ gene that controls anthocyanin spot at the base of the flower petals, belongs to I.

It has been studied anthocyanin pigmentation inheritance and its relationship with the shape of the leaf blade on the lines of the cotton genetic collection [5] [6] [7]. Its monogenic character was noted and the gene controlling the anthocyanin color of the plants was designated as $R_{p}$ (red plant), $R_{s t}{ }^{v}$. It was also found that genes of leaf shape $\left(0_{1}-\mathrm{O}_{1}\right)$ and plant anthocyanin pigmentation $\left(\mathrm{R}_{\mathrm{p}}-\mathrm{r}_{\mathrm{p}}\right)$ are inherited independently.

A complete answer about the anthocyanin pigmentation genetics of cotton can be obtained with a collection of mutants showing complete polymorphism in terms of its localization in various parts of plants. A similar series was created at National University of Uzbekistan and at Institute of Genetics and Experimental Plant Biology of the Academy of Sciences of the Republic of Uzbekistan (IG \& EPB).

Chlorophyll in plant leaves is an importantly ecological and physiological indicator in estimating their viability and photosynthetic productivity. One of the main tasks of cotton growing is to obtain stably high yields of raw cotton with good fiber quality, which depends on the agrotechnical conditions of cultivation. The size and quality of the crop largely depend on the effectiveness of photosynthesis, the chlorophylls presence.

Research of genetic heterogeneity and inheritance of this trait in cotton is of great theoretical and practical interest. According to a number of authors [8] [9] [10] [11] in the ontogenetic development of cotton, the chlorophyll content changes and reaches its maximum in the phase of mass flowering.

\section{Materials and Methods}

The goal of this research is to study the inheritance of anthocyanin pigmentation and the content of chlorophylls on the lines of the genetic collection of Institute of Genetics and Plant Experimental Biology.

The object of the study was the inbred lines of the genetic collection of the cotton plant of Institute of Genetics and Plant Experimental Biology AS of RUz L-2 and L-3, homozygous for the anthocyanin color of plants and chlorophylls. 


\section{Results}

Line-2 with a palmate-lobed leaf shape, anthocyanin coloration in all parts of plant (stem, leaf, flower, box) with unsaturated type of fruit branches, chlorophyll content "a" + "b", $1.32 \pm 0.14$, chlorophyll "a" $0.87 \pm 0.11$, chlorophyll "c" $0.39 \pm 0.16$ was seen from the varietal population of red-leafed Akala, kindly provided by Prof. S. Yunuskhanov.

Line-3 with a palmate-lobed leaf shape and localization of anthocyanin coloration on the stem and veins of the leaf blade, yellowish flower, capsule green, chlorophyll content "a" + "b", $1.70 \pm 0.37$, "a" $1.16 \pm 0.11$, "b", $0.62 \pm 0.11$ isolated from the varietal population of Rowden Mavloni (collection \#011233 of Uzbek Research Institute of Cotton Breeding and Seed Production).

Line L-105 with a palmate-lobed form of a leaf blade with a green-red plant (stem, green leaf, unpainted flower, green box) from the genetic collection of NUUz.

It has been studied the behavior of plants and parental forms of the combination of crosses L- $2 \times \mathrm{L}-3$ and plants $\mathrm{F}_{1}, \mathrm{~F}_{2}$ and $\mathrm{F}_{\mathrm{b}}$.

The obtained material was processed by the $\chi^{2}$ method. Chlorophylls were extracted with $80.0 \%$ acetone solution, the chlorophyll content was determined spectrometric on an SF-16 instrument at $633 \mathrm{~nm}$ and $645 \mathrm{~nm}$, as described in [12] in the mass flowering phase.

\subsection{Inheritance of Anthocyanin Pigmentation}

$\mathrm{F}_{1}$ plants were characterized by maroon color, i.e. in phenotypic expression they differed in more intense anthocyanin coloring than both parental forms resembling the complementary effect of non-allelic genes (Table 1).

In $\mathrm{F}_{2}$ plant, it was observed a clear splitting into four phenotypic classes:

1) Plants with maroon coloring of all parts (stem, leaf, flower and box);

2) Plants with anthocyanin coloring L-2 type (stem, leaf, flower, box);

3) Plants with anthocyanin coloring of L-3 type (stem, venation of the leaf is colored, the flower is unpainted, the box is green);

Table 1. The complementary effect manifestation of anthocyanin color genes.

\begin{tabular}{|c|c|c|c|c|c|c|c|c|c|}
\hline \multirow{2}{*}{ № } & \multirow{2}{*}{ Material } & \multirow{2}{*}{$\boldsymbol{n}$} & \multicolumn{4}{|c|}{ Plant coloration } & \multirow{2}{*}{$\begin{array}{l}\text { theoretical ratio } \\
\text { of phenoclasses }\end{array}$} & \multirow{2}{*}{$x^{2}$} & \multirow{2}{*}{$\mathbf{P}$} \\
\hline & & & Maroon & L-3 type & L-2 type & Green & & & \\
\hline 1. & $\mathrm{~L}-2$ & 50 & - & - & 50 & - & - & - & - \\
\hline 2. & $\mathrm{~F}_{1},(\mathrm{~L}-2 \times \mathrm{L}-3)$ & 80 & 80 & 80 & - & - & - & - & - \\
\hline 3. & $\mathrm{~F}_{2}(\mathrm{~L}-2 \times \mathrm{L}-3)$ & 150 & 84 & 25 & 30 & 11 & $9: 3: 3: 1$ & 0.36 & 0.95 \\
\hline 4. & $\mathrm{~F}_{\mathrm{b}}(\mathrm{L}-2 \times \mathrm{L}-3) \times \mathrm{L}-3$ & 80 & 38 & 42 & - & - & $2: 2$ & 0.20 & $0.70-0.50$ \\
\hline 5. & $\mathrm{~F}_{\mathrm{b}}(\mathrm{L}-3 \times \mathrm{L}-2) \times \mathrm{L}-3$ & 39 & 18 & 21 & - & - & $2: 2$ & 0.92 & $0.70-0.50$ \\
\hline 6. & $\mathrm{~F}_{\mathrm{b}}(\mathrm{L}-3 \times \mathrm{L}-2) \times \mathrm{L}-105$ & 63 & 17 & 15 & 15 & 16 & $1: 1: 1: 1$ & 0.66 & 0.80 \\
\hline 7. & L-105 & 50 & - & - & - & 50 & - & - & - \\
\hline 8. & L-3 & 5 & - & 50 & - & - & - & - & - \\
\hline
\end{tabular}


4) Plants with green coloring of all parts (stem, leaf, unpainted flower, green box).

Their ratio corresponded to 9:3:3:1, in absolute numbers 84:25:30:11, $\chi^{2}=$ $0.36, \mathrm{P}=0.95$.

Analysis of backcross plants $\mathrm{F}_{\mathrm{b}}, \mathrm{F}_{1}(\mathrm{~L}-2 \times \mathrm{L}-3) \times \mathrm{L}-3$ and $\mathrm{F}_{1}(\mathrm{~L}-3 \times \mathrm{L}-2) \times \mathrm{L}-3$ and $F_{1}(\mathrm{~L}-3 \times \mathrm{L}-2) \times \mathrm{L}-105$ confirms the reliability of obtained results in $\mathrm{F}_{2}$ (Table 1).

\subsection{Inheritance of Anthocyanin Coloring of the Plant}

Fact of the complementary effect manifestation of anthocyanin color genes is proved by the analysis of the data in Table 1, revealing the phenoclass ratio 2:2 (1:1), where the first phenotype of maroon color is the result of the presence of both dominant alleles of the anthocyanin color gene with the genotype $R_{p} r_{p} R_{s t}{ }_{s t}^{v} r_{s t}{ }^{v}, R_{p} r_{p} R_{s t}{ }^{v} R_{s t}{ }^{v}, R_{p} R_{p} R_{s t}{ }^{v} r_{s t}{ }^{v}$. If there is no dominant allele in the genotype of any $R_{p}$ or $R_{s l}{ }^{v}$, phenotypically, respectively, from the genotype will appear in plants of the L-3 or L-2 type. Recessive homozygosity for both $\mathrm{r}_{\mathrm{p}} \mathrm{r}_{\mathrm{p}} \mathrm{r}_{\mathrm{st}}{ }^{\mathrm{v}} \mathrm{r}_{\mathrm{st}}{ }^{\mathrm{v}}$ genes will contribute to the phenotype of plants with green coloring.

The final evidence was given by the backcross results $\mathrm{F}_{1}(\mathrm{~L}-2 \times \mathrm{L}-3) \times \mathrm{L}-105$. At the same time, four phenoclasses were obtained at $\mathrm{F}_{\mathrm{b}}, \mathrm{F}_{1}(\mathrm{~L}-2 \times \mathrm{L}-3) \times \mathrm{L}-105$ :

1) Maroon; 2) L-3 type; 3) L-2 type; 4) plants with green coloration as L-105 line. The appearance of plants with maroon color is the result of the formation of the genotype $R_{p} r_{p} R_{s t}{ }^{v}{ }_{s t}{ }^{v}$, L-2 type $R_{p} r_{p} r_{s t}{ }^{v} r_{s t}{ }^{v}$, L-3 type $r_{p} r_{p} R_{s t}{ }^{v} r_{s t}{ }^{v}$ and green plants $r_{\mathrm{p}} \mathrm{r}_{\mathrm{p}} \mathrm{r}_{\mathrm{st}} \mathrm{v}_{\mathrm{st}} \mathrm{v}^{\mathrm{v}}$, in 1:1:1:1 ratio.

In our previous studies [2] [3], the question was emphasized on the possibility of digenic control of the anthocyanin color of a cotton plant.

In contrast to previous studies, this article presents the results of genetic analysis, indicating a complementary interaction of genes involved in the genetic control of genes of plant anthocyanin pigmentation.

The cleavage in $\mathrm{F}_{2}$ due to the complementary interaction of the genes involved in the genetic control of the anthocyanin color of the plant can give the following genetic explanations:

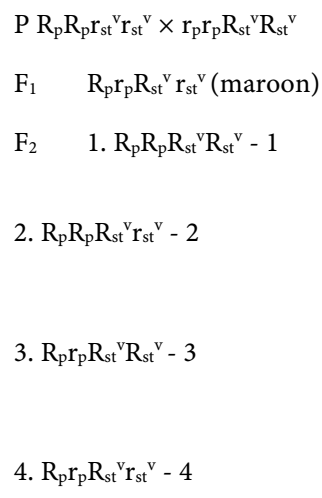




\section{Continued}

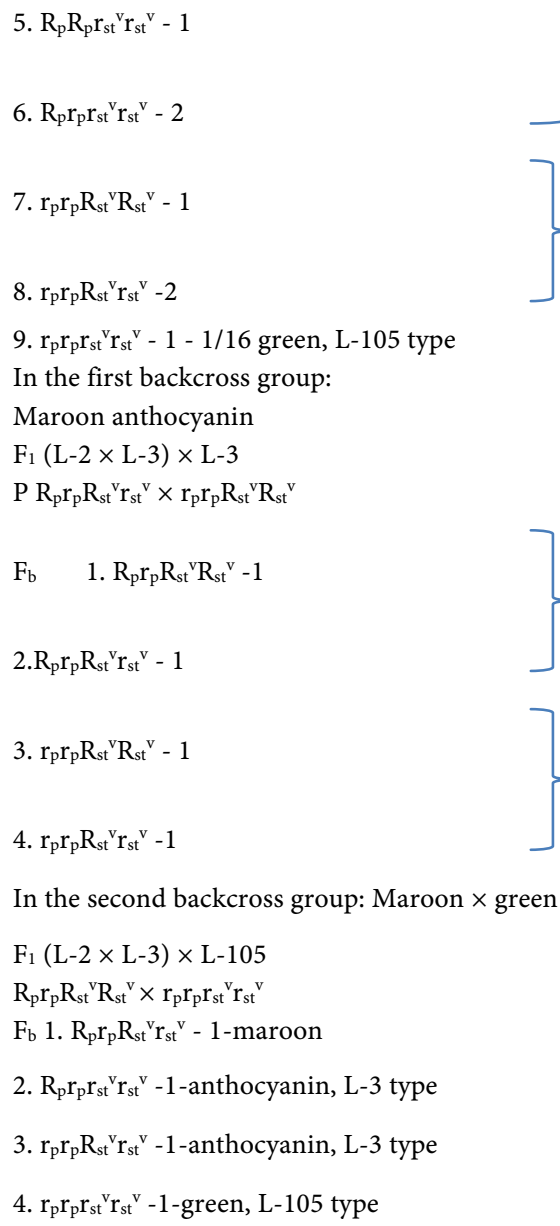

Thus, on the basis of genetic analysis, it can be argued that L-2 and L-3 differ in the allelic state of anthocyanin coloring genes $R_{p}-r_{p}, R_{s t}{ }^{v},-r_{s t}{ }^{v}$, dominant alleles in one genotype act complementary and cause the appearance of maroon color.

\subsection{Inheritance of Chlorophyll Content per Leaf}

Data on the content of "a" and "b" chlorophylls in the parent and hybrid forms are shown in Table 2. L-2 in terms of the content of the sum of chlorophylls "a" + "b" has an indicator of $\mathrm{X}=1.32 \pm 0.11$ and for "a" $\mathrm{X}=0.8 \pm 70.11$, for " $\mathrm{b}$ " $\mathrm{X}=$ $0.39 \pm 0.16$. For L-3, these indicators are slightly higher than for L-2, "a" + " $b$ ” $X$ $=1.70 \pm 0.37$, "a" $1.16 \pm 0.11$, and for "b" $0.62 \pm 0.15$.

In $\mathrm{F}_{1}$ plants $\mathrm{L}-2 \times \mathrm{L}-3$, "a" + "b" amount is $2.21 \pm 0.11$, which indicates the heterosis effect $-\mathrm{hp}=3.68$. According to chlorophyll "a", $-1.37 \pm 0.35$ is relatively weak heterosis, $h p=2.50$. According to chlorophyll " $b$ " $0.79 \pm 0.33$, where $\mathrm{hp}=2.54$, the effect of heterosis is also observed.

Interesting results were obtained for $\mathrm{F}_{\mathrm{b}}(\mathrm{L}-2 \times \mathrm{L}-3) \times \mathrm{L}-3$, where all plants turned out to be anthocyanin-colored: the content of chlorophylls "a" + "b" 
$-1.96 \pm 0.17$, according to “a” $1.44 \pm 0.16$, a dominance effect is observed, and heterosis, respectively, $\mathrm{hp}=0.01$ and 2.00 .

Regularity is observed for chlorophyll " $b$ " $0.50 \pm 0.05$, high variability, hp $=$ -2.62 , that is, the effect of negative heterosis is observed, over dominating compared to $\mathrm{F}_{1}$ and $\mathrm{L}-3$.

The reason for these phenomena is revealed by analyzing the content of chlorophyll in the population $\mathrm{F}_{2}, \mathrm{~L}-2 \times \mathrm{L}-3$ (in one family of $\mathrm{F}_{2}$ plant).

Table 2. Inheritance of the content of chlorophylls "a" + "b", "a" and "b" and their connection with anthocyanin coloration.

\begin{tabular}{|c|c|c|c|c|c|c|c|c|c|c|c|c|c|}
\hline \multirow{2}{*}{ № } & \multirow{2}{*}{ Material } & \multirow{2}{*}{ Chlorophyll } & \multirow{2}{*}{$\mathrm{n}$} & \multicolumn{6}{|c|}{ average value of the classes of mg per $g$ of raw tissue } & \multirow{2}{*}{$\mathrm{X} \pm \mathrm{m}$} & \multirow{2}{*}{$\delta$} & \multirow{2}{*}{$\mathrm{V}$} & \multirow{2}{*}{ hp } \\
\hline & & & & 0.25 & 0.75 & 1.25 & 1.75 & 2.25 & 2.75 & & & & \\
\hline \multirow[t]{3}{*}{1} & $\mathrm{~L}-2$ & “a” \pm "b" & 10 & & & 10 & & & & $1.32 \pm 0.14$ & 0.28 & 6.24 & \\
\hline & & “a” & 10 & & 9 & 1 & & & & $0.87 \pm 0.11$ & 0.24 & 4.12 & \\
\hline & & "b" & 10 & 10 & & & & & & $0.39 \pm 0.16$ & 1.51 & 5.87 & \\
\hline \multirow[t]{3}{*}{2} & $\mathrm{~F}_{1}(\mathrm{~L}-2 \times \mathrm{L}-3)$ & “a” \pm “b” & 10 & & & & 3 & 7 & & $2.21 \pm 0.11$ & 0.23 & 10.45 & 3.68 \\
\hline & & "a" & 10 & & & 10 & & & & $1.37 \pm 0.35$ & 0.11 & 8.37 & 2.50 \\
\hline & & "b" & 10 & & 10 & & & & & $0.79 \pm 0.33$ & 0.16 & 6.88 & 2.54 \\
\hline \multirow[t]{3}{*}{3} & $\mathrm{~F}_{1}(\mathrm{~L}-2 \times \mathrm{L}-3) \times \mathrm{L}-3$ & “a” \pm "b" & 10 & & & 1 & 5 & 4 & & $1.96 \pm 0.17$ & 0.42 & 11.82 & 0.01 \\
\hline & & "a" & 10 & & 1 & 9 & & & & $1.44 \pm 0.16$ & 1.12 & 8.55 & 2.09 \\
\hline & & "b" & 10 & 7 & 3 & & & & & $0.50 \pm 0.05$ & 0.20 & 9.86 & -2.62 \\
\hline \multirow[t]{3}{*}{4} & L-3 & “a" \pm "b" & 10 & & & & 10 & & & $1.70 \pm 0.37$ & 0.14 & 8.31 & \\
\hline & & "a" & 10 & & 5 & 5 & & & & $1.16 \pm 0.11$ & 0.27 & 7.44 & \\
\hline & & "b" & 10 & 7 & 3 & & & & & $0.62 \pm 0.15$ & 0.12 & 4.21 & \\
\hline \multirow[t]{3}{*}{5} & $\mathrm{~F}_{2}(\mathrm{~L}-2 \times \mathrm{L} 3)$ & “a” \pm "b" & 44 & 1 & 13 & 18 & 8 & 4 & & $1.21 \pm 0.45$ & 1.29 & 8.06 & \\
\hline & & “a” & 44 & 7 & 22 & 14 & 1 & & & $0.87 \pm 0.18$ & 1.52 & 7.74 & \\
\hline & & "b" & 44 & 37 & 7 & & & & & $0.32 \pm 0.11$ & 1.52 & 4.67 & \\
\hline \multirow{3}{*}{\multicolumn{2}{|c|}{$\begin{array}{l}\text { Of them: Anthocyanin: } \\
\text { maroon }\end{array}$}} & “a” \pm "b" & 32 & 1 & 8 & 13 & 6 & 4 & & $1,08 \pm 0,10$ & 0.21 & 9.77 & \\
\hline & & “a” & 32 & 4 & 14 & 12 & 2 & & & $1.14 \pm 0.13$ & 0.31 & 7.26 & \\
\hline & & "b" & 32 & 23 & 8 & 1 & & & & $0.52 \pm 0.11$ & 0.80 & 8.05 & \\
\hline \multirow{3}{*}{\multicolumn{2}{|c|}{ Anthocyanin: L-2 type }} & “a" \pm "b" & 6 & & 3 & 3 & & & & $1.14 \pm 0.14$ & 0.21 & 8.44 & \\
\hline & & "a" & 6 & 2 & 3 & 1 & & & & $0.81 \pm 0.29$ & 0.41 & 5.52 & \\
\hline & & "b" & 6 & 6 & & & & & & $0.67 \pm 0.19$ & 0.23 & 4.81 & \\
\hline \multirow{3}{*}{\multicolumn{2}{|c|}{ Anthocyanin: L-3 type }} & “a” \pm "b" & 3 & & 1 & 2 & & & & $1.62 \pm 0.10$ & 0.21 & 13.02 & \\
\hline & & "a" & 3 & & & 1 & 2 & & & $1.74 \pm 0.15$ & 0.26 & 15.30 & \\
\hline & & "b" & 3 & 3 & & & & & & $0.35 \pm 016$ & 0.29 & 9.05 & \\
\hline \multirow{3}{*}{\multicolumn{2}{|c|}{ Green }} & $a " \pm " b "$ & 3 & & 2 & 1 & & & & $0.97 \pm 0.22$ & 0.38 & 9.60 & \\
\hline & & "a" & 3 & 1 & 2 & & & & & $0.67 \pm 0.14$ & 0.25 & 6.95 & \\
\hline & & "b" & 3 & 3 & & & & & & $0.39 \pm 0.08$ & 0.10 & 5.46 & \\
\hline
\end{tabular}


According to the table, in $\mathrm{F}_{2}$ there is a wide range of variability in the content of chlorophylls "a" + "b", that ranges from 0.25 to 2.25 , with an average value of the trait $\mathrm{X}=1.21 \pm 0.45$, with $\mathrm{V}=8.06$. If we consider separately the inheritance of the content of chlorophyll "a" and "b", we can see that they have a kind of genetic control and regularity. The inheritance of chlorophyll "a" is as follows. The indicator of this trait, in the parent forms, $\mathrm{L}-2, \mathrm{X}=1.32 \pm 0.14$, with $\mathrm{V}=6.24$, in $\mathrm{L}-3 \mathrm{X}=1.70 \pm 0.37, \mathrm{~V}=8.31$. In F2 plant - trait fluctuations range from 0.25 to 1.75 at $\mathrm{X}=0.87 \pm 0.18$, at $\mathrm{V}=7.74$. And the chlorophyll " $\mathrm{b}$ " indicator, in the parent form L-2, $\mathrm{X}=0.39 \pm 0.16, \mathrm{~V}=5.87$, in L-3, from 0.25 to $0.75 \mathrm{X}=0.62 \pm$ $0.15, \mathrm{~V}=4.21$. In $\mathrm{F}_{2}$ plant, indicator of this trait was at $\mathrm{X}=0.32 \pm 0.11, \mathrm{~V}=$ $4.67 \%$.

Obtained data indicate that the sign of the content of both chlorophyll "a" and chlorophyll " $b$ " have different genetic controls and therefore they have different degrees of variability in $\mathrm{F}_{2}$ (Table 2).

In order to identify the significance of anthocyanin coloration in the inheritance of indicators of "a" and "b" chlorophylls, we carried out a separate analysis of the inheritance of this trait against the background of the color of the plant. In $\mathrm{F}_{2}$ plants with a darker anthocyanin color, in 32 plants, the total amount of chlorophylls "a" + "b" ranges from 0.25 to $2.25, \mathrm{X}=1.08 \pm 0.10, \mathrm{~V}=9.77$. On chlorophyll "a", the fluctuations of the indicator are from 0.25 to 1.75 , at $\mathrm{X}=$ $1.14 \pm 0.13, V=7.26 \%$, and on chlorophyll " $b$ ", from 0.25 to 1.25 , at $X=0.52 \pm$ $0.11, \mathrm{~V}=8.05$. The same indices for $6 \mathrm{~F}_{2}$ plants with anthocyanin coloration with a phenotypic expression of the type of coloration L-2, chlorophyll "a" + "b" ranged from 0.75 to 1.25 , at $\mathrm{X}=1.14 \pm 0.14, \mathrm{~V}=844$, chlorophyll "a" ranges from 0.25 to 1.25 , at $\mathrm{X}=0.81 \pm 0.23, \mathrm{~V}=5.52$, and chlorophyll " $\mathrm{b}$ " $\mathrm{X}=0.67 \pm$ $0.19, \mathrm{~V}=4.81$. In 3 plants with anthocyanin coloration, type L-3, "a" + "b" ranges from 0.75 to 1.25 , at $\mathrm{X}=1.62 \pm 0.10, \mathrm{~V}=13.02$, while the content of chlorophyll "a" ranges from 1.25 to $1.75, \mathrm{X}=1.74 \pm 0.15, \mathrm{~V}=15.30$ " $\mathrm{b}$ " $\mathrm{X}=0.35$, $\pm 0.16, \mathrm{~V}=9.05$. In 3 green plants, the content of chlorophylls "a" + "b" ranges from 0.75 to $1.25, \mathrm{X}=0.97 \pm 0.22, \mathrm{~V}=9.60 \%$. Chlorophyll "a" fluctuates from 0.25 to $0.75, \mathrm{X}=0.67 \pm 0.14, \mathrm{~V}=6.95 \%$, and chlorophyll "b", $\mathrm{X}=0.39 \pm 0.08, \mathrm{~V}$ $=5.46 \%$.

Thereby, analysis of inheritance of "a" + "b" chlorophylls content in the total for $\mathrm{F}_{2}$ plant with dark burgundy anthocyanin coloration is on average $1.08 \pm$ $0.10, \mathrm{~V}=9.77 \%$, for $\mathrm{F}_{2}$ plants with anthocyanin coloration (L-2 type), $1.14 \pm$ $0.14, \mathrm{~V}=8.44 \%$, for $\mathrm{F}_{2}$ with anthocyanin color, type $\mathrm{L}-3$, much higher than 1.62 $\pm 0.10, \mathrm{~V}=13.02$. In the new phenotype of $F_{2}$-plant with a green color, this indicator is lower $0.97 \pm 0.22, \mathrm{~V}=9.60$. If we closely monitor the inheritance of chlorophylls "a" + "b" in the four phenotypic classes, the highest chlorophyll content in plants of L-3 type, then a plant of L-2 type, then plants $F_{2}$ with maroon color, and a new phenotype with green color (Table 2).

When one considers the inheritance of the trait against the background of chlorophylls "a" or "b", one can see that the content of chlorophyll "a" in the parent L-2 and L-3 lines have significant differences in the average. For L-2 line, 
this indicator is $0.87 \pm 0.11$, for L-3 $1.16 \pm 0.11$, for chlorophyll " $b$ " they also have differences for L-2 $0.39 \pm 0.16$, and L-3 $0.62 \pm 0.15$. Therefore, in $\mathrm{F}_{2}$ plants with anthocyanin coloration, on average, they are much higher in terms of their sum "a" + "b", respectively $1.08 \pm 0.10,1.62 \pm 0.10$ in a plant with green coloration $0.97 \pm 0.22$, significantly less. According to the content of chlorophyll "a" of $\mathrm{F}_{2}$ plants, colored individuals averaged $1.14 \pm 0.13$, type L-2 $0.81 \pm 0.23$, type L-3 $1.74 \pm 0.15$, and the plant had a green color $0.67 \pm 0.14$. Here, L- 3 type is significantly different with the best twice as high levels of chlorophyll "a".

As for chlorophyll " $\mathrm{b}$," $\mathrm{F}_{2}$ plants with maroon pigmentation are $0.52 \pm 0.11$, L-2 type $0.67 \pm 0.12$, L-3 type $0.35 \pm 0.16$, and new phenotype with green color $0.39 \pm 0.08$.

According to the data on $\mathrm{F}_{2}$, the best indicators for chlorophyll content in individuals with anthocyanin pigmentation of L-3 type, both in the sum of "a" + " $b$ " and individually, the content of "a" and "b" of chlorophylls are higher.

Obtained data allow making a conclusion either about the linkage of genes determining the content of chlorophylls in the chromosome linkage group, where $R_{s t}{ }^{v}$ gene is localized or the pleiotropic effect on the formation of both chlorophyll "a" and "b". This is evidenced by the low content of chlorophyll in the $\mathrm{F}_{2}$ plant with a green color characterizing the recessive homozygous state of $r_{p} r_{p}$ и $r_{s t}{ }^{v} r_{s t}{ }^{v}$ genes, especially $r_{s t}{ }^{v}$ gene in genotype.

\section{Conflicts of Interest}

The authors declare no conflicts of interest regarding the publication of this paper.

\section{References}

[1] Hutchinson, J.B. (1932) The Genetics of Cotton. VIII: The Inheritance of Anthocyanin Pigmentation in Asiatic Cottons. Journal of Genetics, 26, 317-339. https://doi.org/10.1007/BF02984492

[2] Harland, S.C. (1939) The Genetics Cotton. Jonathan Cape, London, 193 p.

[3] Stephens, S.C. (1974) Geographic and Taxonomic Distribution of Anthocyanin Genes in New Wold Cottons. Journal of Genetics, 61, 128-141. https://doi.org/10.1007/BF02984077

[4] Kohel, R.J. (1972) Lineage Tests in Upland Cotton. G. hirsutum L. II. Crop Science, 12, 66-69. https://doi.org/10.2135/cropsci1972.0011183X001200010022x

[5] Abzalov, M.F., Tursunov, Ya.B. and Zhurakulov, G.N. (2009) On the Genetics of Anthocyanin Coloration of a Cotton Plant G. hirsutum L. Reports of the Academy of Sciences of the Republic of Uzbekistan, No. 3-4, Tashkent, 101-103.

[6] Abzalov, M.F. and Fathullaeva, G.N. (1993) The Study of the Genetics of Anthocyanin Color of the Plant and Its Relationship with the Shape of the Leaf Blade in Cotton Gossypium hirsutum L. Genetics, 29, 1356-1365.

[7] Abzalov, M.F., Tursunov, Ya.B. and Zhurakulov, G.N. (2012) Inheritance of Chlorophyll Content against the Background of Anthocyanin Pigmentation in Cotton $G$. hirsutum L. Reports of the Academy of Sciences of the Republic of Uzbekistan No. 5, Tashkent, 62-64. 
[8] Abdullaev, H.A. and Karimova, Kh.Kh. (2011) Index of Photosynthesis in Cotton Breeding. Dushanbe, ed. Donish, $267 \mathrm{~s}$.

[9] Krasichkova, G.B., Asoeva, L.M., Giller, Yu.E. and Sanginov, B.S. (1988) The Content of Plastid Pigments in Generations of Hybrids of Fine Fiber Cotton. Dokl. Tazh SSR., 31, 756-759.

[10] Mansurov, A.N. (1991) Physiological-Genetic Analysis of Pyrisigns of Photosynthesis and Productivity in Cotton. Diss.can. biol.nauk-Dushanbe, IF and BR AN RT, 156.

[11] Nasirov, Yu.S. (1975) Photosynthesis and Genetics of Chloroplasts M., Nauka,143 s.

[12] Shlyk A.A. (1971) Definition of Chlorophylls and Carotenoids in Extracts of Angry Leaves. In: Biochemical Methods in the Physiology of Plants, from the "Science", Maskva, 154-170. 